\title{
PENGARUH UPAH, MODAL, TEKNOLOGI DAN PRODUKTIVITAS TERHADAP PENYERAPAN TENAGA KERJA INDUSTRI KECIL PERCETAKAN DI SEBATIK
}

\author{
EFFECT OF CAPITAL, TECHNOLOGY AND \\ PRODUCTIVITY OF MANPOWER ABSORPTION PRINTING \\ IN SMALL INDUSTRIES OF SEBATIK
}

\author{
Mohd Syukur Bin Mohd Ali ${ }^{1)}$, Asih Kusuma Wijayanti ${ }^{2)}$ \\ (Universitas Borneo Tarakan)
}

\begin{abstract}
Abstrak: Penelitian ini bertujuan untuk mengetahui pengaruh upah, modal, teknologi dan produktivitas terhadap penyerapan tenaga kerja industri kecil percetakan di Sebatik dalam penelitian ini adalah data kuantitatif. Populasi dalam penelitian ini adalah semua usaha percetakan di Sebatik. Jumlah sampel usaha percetakan yang sudah peneliti survei adalah 35 sampel usaha percetakan maka peneliti menggunakan metode sampel jenuh dimana peneliti menentukan seтиa anggota populasi untuk dijadikan sampel. Penelitian ini menggunakan metode analisis regresi linear berganda. Hasil penelitian menunjukkan bahwa upah (X1) tidak berpengaruh signifikan terhadap penyerapan tenaga kerja, dengan nilai thitung sebesar $-0,785<t$ tabel 2,042 dan tingkat signifikansi 0,439>0,05. Modal (X2)tidak berpengaruh signifikan terhadap penyerapan tenaga kerja, dengan nilai $t$ hitung sebesar -0,714 < t tabel 2,042 dan tingkat signifikansi 0,481 >0,05. Teknologi (X3) tidak berpengaruh signifikan terhadap penyerapan tenaga kerja, dengan nilai $t$ hitung sebesar 0,713 $<t$ tabel 2,042 dan tingkat signifikansi 0,481>0,05. Produktivitas (X4)berpengaruh signifikan terhadap penyerapan tenaga kerja, dengan nilai $t$ hitung sebesar 2,375 > $t$ tabel 2,042 dan tingkat signifikansi 0,024 >0,05. Upah, modal, teknologi dan produktivitas tidak berpengaruh yang signifikan secara bersama-sama terhadap penyerapan tenaga kerja, dengan nilai $F$ hitung sebesar 1,699 < F tabel 2,042 dan tingkat signifikansi 0,176>0,05. Dan diperoleh nilai koefisien determinasi (R2) sebesar 0,185 atau 18,5 persen. Nilai tersebut menunjukkan bahwa 18,5 persen penyerapan tenaga kerja dipengaruhi oleh upah, modal, teknologi, dan produktivitas sedangkan sisanya 81,5 persen dipengaruhi oleh faktor lain yang tidak dimasukkan dalam model.
\end{abstract}

Kata Kunci: Analisis Regresi Linear Berganda, Upah, Modal, Teknologi, Produktivitas Penyerapan Tenaga Kerja

Abstract: This study aims to determine the effect of wages, capital, technology and productivity on the absorption of small-scale printing industry labor in Sebatik in this study is qualitative descriptive. The population in this study were all printing businesses in Sebatik. The number of sample printing businesses that have been surveyed by researchers are 35 samples of printing businesses, so the researcher uses saturated sample 
method where the researcher determines all members of the population to be sampled. This study uses multiple linear regression analysis methods.

The results showed that wages $\left(X_{1}\right)$ had a significant effect on labor absorption, with a $t$ value of $0.455<t$ table 2.042 and a significance level of 0.341. Capital $\left(\mathrm{X}_{2}\right)$ has a significant effect on employment, with a t count of $0.304>$ t table 2.042 and a significance level of -0.140. Technology $\left(X_{3}\right)$ has a significant effect on labor absorption, with a $t$ value of $1.610<t$ table 2.042 and a significance level of 0.347. Productivity $\left(X_{4}\right)$ has a significant effect on labor absorption, with a $t$ count of 0.544> $t$ table 2.042 and $a$ significance level of 0.041. Wages, capital, technology and productivity have no significant effect together on employment, with an $F$ count of 1.603 $<F$ table 2.690 and a significance level of 0.199>0.05. And obtained coefficient of determination $\left(R_{2}\right)$ of 0.185 or 18.5 percent. This value shows that 18.5 percent of employment absorption is influenced by wages, capital, technology, and productivity while the remaining 81.5 percent is influenced by other factors not included in the model.

Keywords: Multiple Linear Regression Analysis, Wages, Capital, Technology, Productivity, Labor Absorption.

\section{LATAR BELAKANG}

Penyerapan tenaga kerja merupakan jumlah tenaga kerja yang bekerja dalam suatu unit usaha tertentu. Salah satu cara untuk memperluas penyerapan tenaga kerja adalah melalui pengembangan industri terutama industri yang bersifat padat karya. Perkembangan dapat terwujud melalui investasi swasta maupun pemerintah. Pengembangan industri tersebut akan menyebabkan kapasitas produksi meningkat sehingga dapat menciptakan kesempatan kerja. Tenaga kerja yang mampu diserap dari penyerapan tenaga kerja tergantung dari upah, modal, produktivitas dan teknologi (Zamrowi, 2007).

Tenaga kerja adalah semua orang yang bersedia untuk bekerja. Pengertian tenaga kerja ini meliputi mereka yang bekerja untuk diri sendiri ataupun anggota keluarga

yang tidak menerima bayaran berupa upah atau mereka yang sesungguhnya bersedia dan mampu untuk bekerja, dalam arti mereka menganggur dengan terpaksa karena tidak ada kesempatan kerja (Sumarsono, 2009).Penyerapan Tenaga Kerja merupakan jumlah tenaga kerja yang bekerja dalam suatu unit usaha tertentu. Salah satu cara untuk memperluas penyerapan tenaga kerja adalah melalui perkembangan industri yang bersifat padat karya. Perkembangan industri tersebut akan menyebabkan kapasitas produksi meningkat sehingga dapat menciptakan kesempatan kerja (Divianto, 2014: 48). 
Usaha Kecil Menengah (UKM) adalah tulang punggung ekonomi Indonesia.Jumlah UKM hingga 2011 mencapai 52 juta. UKM di Indonesia sangat penting bagi ekonomi karena menyumbangkan $60 \%$ dari PDB dan menampung $97 \%$ tenaga kerja. Usaha Mikro, Kecil dan Menengah (UMKM) merupakan usaha kerakyatan yang saat ini mendapat perhatian dan keistimewaan yang diamanatkan oleh Undang-Undang

Pulau Sebatik merupakan salah satu pulau kecil yang berbatasan daratan dengan Malaysia, yang wilayahnya terbagi menjadi dua bagian, antara lain: (1) wilayah Negara Malaysia, dan (2) wilayah Negara Indonesia. Pulau Sebatik terdiri dari 5 Kecamatan dan 19 Desa yang siap menjadi DOB ( Daerah Otonomi Baru). Jumlah penduduk Sebatik telah mencapai 37,992 jiwa pada tahun 2015. Jumlah penduduk di wilayah Sebatik mencapai 39,145 jiwa yang tersebar di lima kecamatan, yaitu Kecamatan Sebatik 4,787 jiwa, Kecamatan Sebatik Barat 8,075 jiwa, Kecamatan Sebatik Tengah 7,559 jiwa, Kecamatan Sebatik Timur 12,904 jiwa, dan Kecamatan Sebatik Utara 5,820 jiwa (BPS Kabupaten Nunukan, 2017).

Berdasarkan latar belakang permasalahan yang telah dipaparkan di atas, maka peneliti tertarik melakukan penelitian ilmiah yang berjudul "Pengaruh Modal, Teknologi Dan Produktivitas Terhadap
Penyerapan Tenaga Kerja Industri Kecil Percetakan di Sebatik.

\section{RUMUSAN MASALAH}

Berdasarkan latar belakang tersebut maka rumusan masalah yang akan diteliti adalah: Bagaimana pengaruh upah, modal, teknologi dan produktivitas secara parsial dan simultan terhadap penyerapan tenaga kerja pada industri kecil percetakan di Sebatik

\section{TUJUAN PENELITIAN}

Berdasarkan

latar belakang dan rumusan masalah di atas, maka tujuan penelitian ini adalah: Untuk mengetahui pengaruh upah, modal,

\section{TINJAUAN PUSTAKA}

\section{$\underline{\text { Teori Industri }}$}

Istilah industri secara ekonomi dapat diartikan sebagai kegiatan pengolahan bahan mentah menjadi barang yang sudah jadi atau barang setengah jadi.Kegiatan pengolahan di sini dapat dilakukan secara manual, dengan mesin, maupun secara elekronik.Istilah industri dapat diartikan sebagai himpunan perusahaan-perusahaan sejenis, dimana kata industri dirangkai dengan kata yang menerangkan jenis industrinya. Misalnya, industri obat-obatan, industri permen, industri perkayuan, dan sebagainya (Subandi, 2006). 


\section{$\underline{\text { Produktivitas }}$}

Produktivitas adalah jumlah hasil yang dicapai oleh seseorang pekerja atau unit faktor lain dalam jangka waktu tertentu. Produktivitas pada dasarnya adalah suatu sikap mental yang selalu mempunyai pandangan bahwa mutu kehidupan hari ini lebih baik daripada hari kemarin, dan hari esok lebih baik dari ini (Sinungan 2005 : 16).

\section{$\underline{\text { Tinjauan Empiris }}$}

Redeptus Henry, (2015), berjudul Analisis Penyerapan Tenaga Kerja Pada Usaha Percetakan Skala Kecil Menengah di Kota Malang. Metode analisis yang digunakan dalam penelitian ini adalah regresi linier berganda, analisis regresi ini kita gunakan untuk menguji model penyerapan tenaga kerja. Adapun hasil dari penelitian ini yaitu, pemberian upah yang diberikan pengusaha usaha percetakan kepada pekerja masih jauh dibawa upah minimum kota malang. Upah Minimum Kota Malang saat ini yang berjumlah 1.882.250 ini masih jauh jika dibandigkan dengan upah yang diterima oleh pekerja.

Divanto,(2014), berjudul pengaruh upah, modal, produktivitas, dan teknologi terhadap penyerapan tenaga kerja usaha kecil-menengah di Kota Palembang (studi kasus usaha percetakan). Metode analisis yang digunakan pada penelitian ini adalah bahwa hanya variabel modal yang berpengaruh signifikan dan positif terhadap penyerapan tenaga kerja.

\section{$\underline{\text { Hipotesis }}$}

Diduga upah, modal, teknologi dan produktivitas berpengaruh signifikan secara parsial dan simultan terhadap penyerapan tenaga kerja pada industri kecil percetakan di Sebatik

\section{$\underline{\text { Kerangka Penelitian }}$}

Kerangka penelitian ini menjelaskan bahwa penyerapan tenaga kerja yang merupakan variabel dependen (terikat) berpengaruh terhadap tiga variabel independen (bebas).Penelitan ini menganalisis pengaruh modal, teknologi, dan produktivitas terhadap penyerapan tenaga kerja industri percetakan di Sebatik.Variabel dependen (terikat) dalam penelitian ini yaitu penyerapan tenaga kerja.

Penyerapan tenaga kerja pada industri kecil percetakan di Sebatik dijadikan sebagai variabel terikat.Sedangkan variabel independen (bebas) dalam penelitian ini yaitu modal, teknologi dan produktivitas.

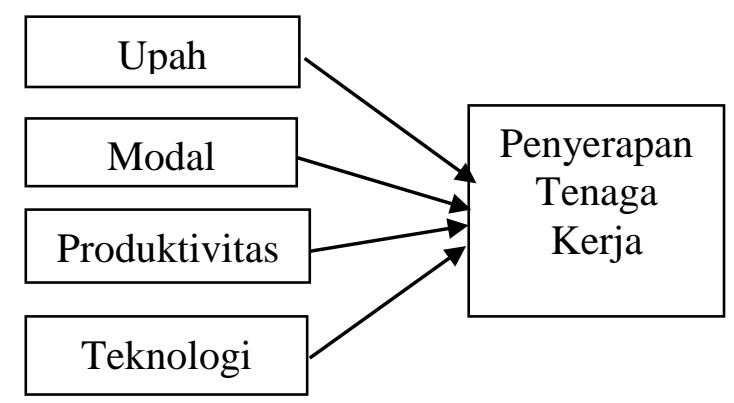


Kerangka penelitian yang di atas dapat dijelaskan sebagai berikut:

1. Judul penelitian yang terdiri dari variabel dependen (terikat) dan variabel independen (bebas) yaitu penyerapan tenaga kerja, upah, modal, teknologi dan produktivitas.

2. Dari judul penelitian yang demikian itu, dilakukan pengelolaan menggunakan alat analisis. Alat analisis yang digunakan adalah analisis regresi linier berganda untuk mengukur pengaruh modal, teknologi dan produktivitas terhadap penyerapan tenaga kerja industri di Sebatik.

3. Hasil akhir terdiri dari pokokpokok kesimpulan dan saran yang didapat dari pembahasan hasil penelitian. 4. Dengan kerangka penelitian yang demikian itu, maka diasumsikan bahwa terdapat pengaruh positif (searah) variabel modal, teknologi dan produktivitas terhadap penyerapan tenaga kerja industri kecil di Sebatik.

\section{METODOLOGI PENELITIAN}

\section{$\underline{\text { Desain Penelitain }}$}

Penulisan penelitian ini menggunakan pendekatan kuantitatif dimana peneliti ingin mengetahui pengaruh penyerapan tenaga kerja industri kecil percetakan di Sebatik.
Objek, Lokasi Penelitian, dan $\underline{\text { Waktu Penelitian }}$

Objek dalam penelitian ini adalah tenaga kerja di industri kecil percetakan yang berada di Sebatik. Tempat pelaksanaan penelitian ini adalah seluruh industri kecil percetakan yang berada di Sebatik. Penelitian ini dilaksanakan pada semester genap tahun 2018. Lokasi Penelitian ini dilaksanakan di Sebatik, Kalimantan Utara dan waktu penelitian ini di lakukan mulai bulan Mei-Juni 2018

\section{$\underline{\text { Populasi dan Sampel }}$}

Sampel adalah bagian dari jumlah dan karakteristik yang dimiliki oleh populasi tersebut. Apabila peneliti melakukan penelitian terhadap populasi yang besar, sementara peneliti ingin meneliti tentang populasi tersebut dan peneliti memiliki keterbatasan dana, tenaga dan waktu, maka peneliti menggunakan teknik pengambilan sampel, sehingga generalisasi kepada populasi yang diteliti. Maknanya sampel yang diambil dapat mewakili bagi populasi tersebut (Sugiyono, 2013).

Populasi dalam penelitian ini adalah semua usaha percetakan di Sebatik. Karena jumlah usaha percetakan yang sudah peneliti survei adalah 35 usaha percetakan maka peneliti menggunakan metode sampel jenuh dimana peneliti menentukan semua anggota populasi untuk dijadikan sampel 


\section{$\underline{\text { Data Penelitian }}$}

1. Data primer berkaitan dengan data yang dikumpulkan untuk memenuhi kebutuhan penelitian yang dilakukan dan diperoleh dengan wawancara langsung serta melakukan pengisian kuisioner oleh para penguasa percetakan. Data primer diperlukan untuk mengetahui jiumlah tenaga kerja yang bekerja dan lainnya yang berhubungan dengan penelitian.

2. Data sekunder merupakan data pelengkap diperoleh dengan cara pencatatan data-data dari literatur atau bahan bacaan yang ada dan dari instansiinstansi yang terkait.

Definisi Operasional dan Pengukuran Variabel

1. Variabel dependen (Y)

Variabel dependen atau variabel terikat adalah suatu variabel yang dipengaruhi variabel independen.Dalam penelitian ini sebagai variabel terikat adalah penyerapan tenaga kerja yang dimana jumlah atau banyaknya orang yang bekerja pada industri kecil percetakan di daerah Sebatik yang dinyatakan dalam satuan orang.

2. Variabel Independen

Variabel independen atau variabel bebas merupakan variabel yang tidak berpengaruh terhadap variabel lainnya dimana dalam penelitian ini terdapat beberapa variabel bebas, di antaranya:

a. Upah

Upah dalam penelitian ini adalah tingkat upah ratarata yang dibayarkan pengusaha dalam waktu satu bulan dalam satuan ribuan rupiah.

b. Modal

Modal dalam penelitian ini adalah dana yang digunakan dalam proses produksi saja, tidaktermasuk nilai tanah dan bangunan yang ditempati atau lebih dikenal dengan modal kerja. Diukur dalam satuan rupiah.

c. Teknologi

Teknologi dalam penelitian ini adalah mesin produksi yang digunakan pada industri percetakan diukur dalam satuan jumlah atau unit barang.

d. Produktivitas

Produktivitas yang dimaksud dalam penelitian ini adalah nilai rata-rata dalam unit barang yang dapat dihasilkan oleh tenaga kerja atau karyawan pengukuran dalam satuan lembar.

\section{Metode Analisis Data}

Analisis data adalah proses mencari dan menyusun secara sistematis data yang diperoleh dari hasil wawancara, catatan lapangan, dan bahan-bahan lain sehingga dapat mudah dipahami dan temuannya dapat diinformasikan kepada orang lain (Sugiyono, 2013). Model regresi linier dapat disebut sebagai model 
Kecamatan Sebatik Tengah. (BPS Kabupaten Nunukan, 2015b).

Total luas wilayah Sebatik sekitar 246,61 km persegi dengan luas wilayah hutan yang dapat dikonservasi 375,52 ha. Sementara itu, jumlah penduduk di wilayah Sebatik mencapai 40,645 jiwa yang tersebar di lima kecamatan, yaitu Kecamatan Sebatik 5,419 jiwa, Kecamatan Sebatik Barat 8,193 jiwa, Kecamatan Sebatik Tengah 7,430 jiwa, Kecamatan Sebatik Timur 12,966 jiwa, dan Kecamatan Sebatik Utara 6,637 jiwa (BPS Kabupaten Nunukan, 2015b). Berdasarkan jumlah tersebut, sebagian besar penduduknya adalah pendatang dari Bugis, Jawa, dan Flores (Nusa Tenggara Timur) dengan mata pencaharian utama sebagai nelayan, kecuali beberapa di wilayah Sebatik Tengah yang sebagian besar berprofesi sebagai petani dengan mengelola perkebunan sawit, kakao, dan pisang (BPS Kabupaten Nunukan, 2015d).

\section{$\underline{\text { Deskriptif Variabel Penelitian }}$}

Data yang dikumpulkan dalam penelitian ini merupakan data primer yang didapatkan melalui penyebaran kuesioner sebanyak 35 kuesioner. Adapun data yang terkumpul dengan 35 respondenyang dibagikan dengan menggunakan kuisioner adalah sebagai berikut:
Tabel 1. Distribusi Responden Meurut Tenaga Kerja

\begin{tabular}{|c|c|c|}
\hline $\begin{array}{c}\text { Banyaknya } \\
\text { Tenaga } \\
\text { Kerja } \\
\text { (Orang) }\end{array}$ & $\begin{array}{c}\text { Jumlah } \\
\text { Industri } \\
\text { Percetakan }\end{array}$ & $\begin{array}{c}\text { Perse } \\
\text { ntasi } \\
(\%)\end{array}$ \\
\hline $\mathbf{2}$ & $\mathbf{1 7}$ & $\mathbf{4 9}$ \\
\hline $\mathbf{3}$ & $\mathbf{1 3}$ & $\mathbf{3 7}$ \\
\hline $\mathbf{4}$ & $\mathbf{5}$ & $\mathbf{1 4}$ \\
\hline Jumlah & $\mathbf{3 5}$ & $\mathbf{1 0 0}$ \\
\hline
\end{tabular}

Sumber: Data Primer Diolah, 2018

Tabel di atas menunjukkan bahwa 17 industri kecil percetakan menggunakan tenaga kerja 2 orang dengan persentase 49\%, 13 industri kecil percetakan menggunakan tenaga kerja 3 orang dengan persentase $37 \%$ dan 5 industri kecil percetakan menggunakan tenaga kerja 4 orang dengan persentase $14 \%$.

\section{Tabel 2 Distribusi Responden} Menurut Upah

\begin{tabular}{|c|c|c|c|}
\hline No & $\begin{array}{c}\text { Upah/bulan } \\
\text { (Rp.000) }\end{array}$ & Jumlah & $\begin{array}{c}\text { Persenta } \\
\text { se }(\%)\end{array}$ \\
\hline 1 & Rp. 500.000 & 14 & 40 \\
\hline 2 & Rp. 600.000 & 8 & 23 \\
\hline 3 & Rp. 700.000 & 7 & 20 \\
\hline 4 & Rp. 800.000 & 4 & 11 \\
\hline 5 & Rp.1.000.000 & 2 & 6 \\
\hline \multicolumn{2}{|r|}{ Jumlah } & 35 & 100 \\
\hline
\end{tabular}

Sumber: Data Primer Diolah, 2018

Tabel di atas menjelaskan upah tetap industri kecil percetakan di Sebatik yang di berikan dalam sebulan. Data tersebut menunjukkan bahwa 14 industri percetakan memberikan upah kepada karyawan sebesar Rp 500,000 dengan persentase $40 \%$, 8 industri percetakan memberikan 
upah kepada karyawan sebesar Rp 600,000 dengan persentase $23 \%$, 7 industri percetakan memberikan upah kepada karyawan sebesar Rp 700,000 dengan persentase $20 \%$, 4 industri percetakan memberikan upah kepada karyawan sebesar Rp 800,000 dengan pesentase $11 \%$, dan 2 industri kecil percetakan memberikan upah kepada karyawan sebesar Rp 1,000,000 dengan persentase $6 \%$.

Tabel 3. Distribusi Responden Menurut Modal

\begin{tabular}{|c|l|c|c|}
\hline No & $\begin{array}{c}\text { Modal } \\
(\mathbf{R p . 0 0 0})\end{array}$ & Jumlah & $\begin{array}{c}\text { Persentase } \\
(\mathbf{\%})\end{array}$ \\
\hline 1 & $\begin{array}{l}0 \mathrm{~s} / \mathrm{d}< \\
1,000,000\end{array}$ & 15 & 43 \\
\hline 2 & $\begin{array}{l}1,000,000 \\
\text { s/d < } \\
2,000,000\end{array}$ & 10 & 29 \\
\hline 3 & $\begin{array}{l}2,000,000 \\
\text { s/d < } \\
3,000,000\end{array}$ & 5 & 14 \\
\hline 4 & $\begin{array}{l}3,000,000 \\
\text { s/d } \\
<5,000,00 \\
0\end{array}$ & 5 & 14 \\
\hline \multicolumn{2}{|c|}{ Jumlah } & $\mathbf{3 5}$ & $\mathbf{1 0 0}$ \\
\hline
\end{tabular}

Sumber: Data Primer Diolah, 2018

Tabel di atas menjelaskan modal tidak tetap industri kecil di Sebatik yang dibutuhkan dalam jangka waktu perbulan. Data tersebut menunjukkan bahwa 15 industri percetakan menggunakan modal $\mathrm{Rp} 0$ s/d < Rp 1,000,000 dengan persentase $43 \%, \quad 10$ industri percetakan menggunakan modal Rp 1,000.000 s/d < Rp $2,000.000$ dengan persentase $29 \%, 5$ industri percetakan menggunakan modal $\mathrm{Rp}$ $2,000,000$ s/d $<\operatorname{Rp~3,000,000~}$ dengan persentase $14 \%$, dan 5 industri percetakan menggunakan modal $\mathrm{Rp} 3,000,000$ s/d $<\mathrm{Rp}$ $5,000,000$ dengan persentase $14 \%$.

\section{Tabel 4. Distribusi Responden Menurut Teknologi}

\begin{tabular}{|c|c|c|c|}
\hline No & $\begin{array}{c}\text { Teknologi } \\
\text { (unit } \\
\text { barang) }\end{array}$ & Jumlah & $\begin{array}{c}\text { Persentase } \\
(\%)\end{array}$ \\
\hline 1 & $1-5$ & 17 & 49 \\
\hline 2 & $5-10$ & 14 & 40 \\
\hline 3 & $10-15$ & 4 & 11 \\
\hline \multicolumn{2}{|c|}{ Jumlah } & 35 & 100 \\
\hline
\end{tabular}

Sumber: Data Primer Diolah. 2018

Tabel diatas menunjukkan 17 industri percetakan memiliki 15 unit teknologi dengan persentase 49\%, 14 industri percetakan memiliki 5-10 unit teknologi dengan persentase $40 \%$, dan 4 industri percetakan memiliki 10-15 unit teknologi dengan persentase $11 \%$.

Tabel 5. Distribusi Responden Menurut Produktivitas

\begin{tabular}{|c|c|c|c|}
\hline No & $\begin{array}{c}\text { Produktivitas } \\
\text { (lembar) }\end{array}$ & Jumlah & $\begin{array}{c}\text { Persenta } \\
\text { se }(\%)\end{array}$ \\
\hline 1 & $50-100$ & 3 & 9 \\
\hline 2 & $100-500$ & 6 & 17 \\
\hline 3 & $500-1,000$ & 5 & 14 \\
\hline 4 & $1,000-2,000$ & 10 & 29 \\
\hline 5 & $2,000-3,000$ & 11 & 31 \\
\hline & Jumlah & 35 & 100 \\
\hline
\end{tabular}

Tabel di atas menunjukkan 3 industri percetakan dengan produktivitas tenaga kerja 50 sampai 100 lembar dengan persentase $9 \%, 6$ industri percetakan dengan produktivitas tenaga kerja 100 sampai 500 
lembar dengan persentase $17 \%, 5$ industri percetakan dengan produktivitas tenaga kerja 500 sampai 1,000 lembar dengan persentase 14\%, 10 industri percetakan dengan produktivitas tenaga kerja 1,000 sampai 2,000 lembar dengan persentase $29 \%$, dan 11 industri percetakan dengan produktivitas tenaga kerja 2,000 sampai 3,000 lembar dengan persentase $31 \%$.

\section{Hasil Pengujian Asumsi Klasik} $\underline{\text { Hasil Uji Normalitas }}$

Uji normalitas berguna untuk membuktikan data dari sempel yang dimiliki berasal dari populasi berdistribusi normal atau data populasi yang dimiliki berdistribusi tidak normal.Model regresi yang baik adalah memiliki nilai residual yang berdistribusi normal.Uji normalitas pada penelitian ini menggunakan P-P Plot Normality Test dengan melihat nilai asymp.Sig. (2tailed). Apabila nilai hasil pengujian pp plot diperoleh nilai yang lebih besar dari $a=0,05$ berarti residual data sudah berdistribusi normal.

Tabel 6. Ringkasan hasil uji normalitas

\begin{tabular}{|c|c|}
\hline $\begin{array}{c}\text { Kolmogorov- } \\
\text { Smirnov Z }\end{array}$ & 0,784 \\
\hline $\begin{array}{c}\text { Asymp. Sig. (2- } \\
\text { tailed) }\end{array}$ & 0,571 \\
\hline
\end{tabular}

Sumber: Data Primer Diolah, 2018

Berdasarkan tabel di atas, hasil uji normalitas menunjukkan nilai signifikansi $0,571>0,05$ sehingga dapat dikatakan nilai residual pada model persamaan regresi berdistribusi normal.

\section{$\underline{\text { Hasil Uji Multikolinearitas }}$}

Uji multikolinearitas bertujuan untuk mengetahui apakah ditemukan adanya kolerasi antara variabel bebas pada persamaan regresi.Ada tidaknya multikolinearitas dapat dilihat dari nilai koefisien korelasi antar masing-masing variable bebas.Berdasarkan hasil pengujian korelasi, dapat diketahui besarnya nilai koefisien korelasi antar masingmasing variable bebas berikut ini

\section{Tabel 7. Ringkasan Hasil Uji Multikolinearitas}

\begin{tabular}{|c|c|c|}
\hline Variabel & Tolerance & Vif \\
\hline Upah (X1) & 0,682 & 1,466 \\
\hline Modal (X2) & 0,762 & 1,312 \\
\hline Teknologi (X3) & 0,717 & 1,394 \\
\hline Produktivitas (X4) & 0,890 & 1,124 \\
\hline
\end{tabular}

Sumber: Data Primer Diolah, 2018

Berdasarkan tabel di atas dapat diketahui bahwa variabel upah memiliki tolerance value sebesar $0,682>0,1$ dan VIF sebesar $1,466<10$ maka variabel upah tidak terjadi multikolinearitas. Variabel modal memiliki tolerance value sebesar $0,762>0,1$ dan VIF sebesar $1,312<10$ maka variabel modal tidak terjadi multikolinearitas. Variabel teknologi memiliki tolerance value sebesar $0,717>$ 0,1 dan VIF sebesar $1,394<10$ maka variabel teknologi tidak terjadi multikolinearitas, dan variabel produktivitas memiliki tolerance value sebesar $0,890>$ 
0,1 dan VIF sebesar $1,124<10$ maka variabel produktivitas tidak terjadi multikolinearitas. Dapat disimpulkan bahwa antara variabel upah, modal, teknologi dan produktivitas tidak saling mempengaruhi satu dengan yang lain atau tidak terjadi multikolinearitas

\section{$\underline{\text { Hasil Uji Heterokedastisitas }}$}

Dalam penelitian ini uji heterokedastisitas dilakukan dengan menggunakan metode Glejser di mana metode ini melihat nilai thitung dan ttabel atau melihat nilai signifikansi/ probabilitas. Jika $t$ hitung $<\mathrm{t}$ tabel atau nilai signifikansi/ probabilitas lebih besar dari 0,05 maka tidak terjadi heterokedastisitas. Untuk mengetahui nilai thitung dan ttabel atau nilai signifikansi/ probabilitas.

Tabel 8. Ringkasan Hasil Uji Heterokedastisitas

\begin{tabular}{|c|c|}
\hline Variabel & Sig \\
\hline Upah (X1) & 0,934 \\
\hline Modal (X2) & 0,571 \\
\hline Teknologi (X3) & $0,944)$ \\
\hline $\begin{array}{c}\text { Produktivitas } \\
\text { (X4) }\end{array}$ & 0,193 \\
\hline
\end{tabular}

Sumber: Data Primer Diolah, 2018

Berdasarkan tabel di atas dapat diketahui bahwa variabel upah memiliki nilai Sig sebesar 0,934> 0,05 maka dapat disimpulkan bahwa variabel tersebut memenuhi syarat tidak terjadi heterokedasitisitas, variabel modal nilai Sig sebesar 0,571> 0,05 maka dapat disimpulkan bahwa variabel tersebut memenuhi syarat tidak terjadi heterokedasitisitas, variabel teknologi nilai Sig sebesar 0,944>0,05 maka dapat disimpulkan bahwa variabel tersebut memenuhi syarat tidak terjadi heterokedasitisitas, dan variabel modalnilai Sig sebesar 0,193> 0,05 maka dapat disimpulkan bahwa variabel tersebut memenuhi syarat tidak terjadi heterokedasitisitas Dapat disimpulkan bahwa variabel upah, modal, teknologi dan produktivitas tidak terjadi heterokedasitisitas.

\section{$\underline{\text { Regresi Linear Berganda }}$}

Dari hasil regresi dengan menggukan program SPSS 16.0 maka didapatkan koefisien regresi yang dapat dilihat pada tabel

\section{Tabel 9. Ringkasan Hasil Uji} Regresi Linear Berganda

\begin{tabular}{|c|c|c|c|c|}
\hline Variable & B & $\begin{array}{l}\text { Std. } \\
\text { eror }\end{array}$ & $\mathbf{t}$ & sig \\
\hline Konstanta & 1,716 & 1,432 & 1,198 & 0,240 \\
\hline Upah (X1) & $\begin{array}{c}- \\
0,199\end{array}$ & 0,254 & $-0,785$ & 0,439 \\
\hline $\begin{array}{c}\text { Modal } \\
\text { (X2) }\end{array}$ & $\begin{array}{c}- \\
0,058 \\
\end{array}$ & 0,082 & $-0,714$ & 0,481 \\
\hline $\begin{array}{l}\text { Teknologi } \\
\text { (X3) }\end{array}$ & 0,097 & 0,136 & 0,713 & 0,481 \\
\hline $\begin{array}{c}\text { Produktivit } \\
\text { as (X4) }\end{array}$ & 0,108 & 0,045 & 2,375 & 0,024 \\
\hline
\end{tabular}

Sumber: Data Primer Diolah, 2018

Berdasarkan hasil perhitungan regresi linear berganda maka persamaan regresi berganda:

1. Nilai konstanta $(\beta 0)=1,716$

2. Nilai Koefisien $(\beta 1)=0,199$

3. Nilai Koefisien $(\beta 2)=0,058$

4. Nilai Koefisien $(\beta 3)=0,097$

5. Nilai Koefisien $(\beta 4)=0,108$ 
Hasil pengujian hipotesis

\section{Uji-t (Parsial)}

Uji $t$ digunakan untuk menunjukkan berapa jauh pengaruh satu variabel independen upah (X1),modal (X2), teknologi (X3), dan produktivitas (X4) secara individu dalam menerangkan variabel dependen penyerapan tenaga kerja (Y). Hipotesis ini menggunakan tingkat kesalahan 5\% sehingga besarnya $\mathrm{dk}$ (Derajat Koefisien) pembilang $=0,025(0,05 / 2)$ dan $\mathrm{dk}$ penyebut $=(35-4-1)=30$. Maka besarnya t tabel adalah 2,042

Tabel 10 . Hasil Uji-t

\begin{tabular}{|c|c|c|}
\hline Variabel & $\mathbf{t}$ & $\begin{array}{c}\text { Sig./probabi } \\
\text { litas }\end{array}$ \\
\hline Upah (X1) & $-0,785$ & 0,439 \\
\hline Modal (X2) & $-0,714$ & 0,481 \\
\hline $\begin{array}{c}\text { Teknologi } \\
\text { (X3) }\end{array}$ & 0,713 & 0,481 \\
\hline $\begin{array}{c}\text { Produktivitas } \\
\text { (X4) }\end{array}$ & 2,375 & 0,024 \\
\hline
\end{tabular}

Sumber: Data Primer Diolah, 2018

\section{Variabel Upah (X1)}

Hasil dari pengujian hipotesis didapatkan t-statistik variabel upah (X1) sebesar 0,785dan nilai ttabel sebesar 2,042 karena tstatistik $-0,785$ $<$ ttabel 2,042dan prob tstatistik0,439 >0,05 maka, H0 diterima dan Ha ditolak sehingga dapat disimpulkan bahwa upah tidak berpengaruh signifikan secara parsial terhadap penyerapan tenaga kerja industri kecil di Sebatik.

\section{$\underline{\text { Variabel Modal (X2) }}$}

Hasil dari pengujian hipotesis didapatkan t-statistik variabel modal (X2) sebesar 0,714dan nilai ttabel sebesar 2,042 karena tstatistik $-0,714$ $<$ ttabel2,042 dan prob tstatistik0,481> $\quad 0,05$ makaH0diterima dan $\mathrm{Ha}$ ditolak sehingga dapat disimpulkan bahwa modal tidak berpengaruh signifikan secara parsial terhadap penyerapan tenaga kerja industri kecil di Sebatik.

\section{Variabel Teknologi (X3)}

Hasil dari pengujian hipotesis didapatkan t-statistik variabel teknologi (X3) sebesar 0,713dan nilai ttabel sebesar 2,042 karena tstatistik $0,713<$ ttabel 2,042 dan prob tstatistik $\quad 0,481>0,05 \quad$ maka, HOditerima dan $\mathrm{Ha}$ ditolaksehingga dapat disimpulkan bahwa teknologi tidak berpengaruh signifikan secara parsial terhadap penyerapan tenaga kerja industri kecil di Sebatik.

\section{Variabel produktivitas (X4)}

Hasil dari pengujian hipotesis didapatkan t-statistik variabel produktivitas (X4) sebesar 2,375dan nilai ttabel sebesar 2,042 karena t-statistik 2,375>ttabel 2,042 dan prob tstatistik0,024 < 0,05 maka, HOditolak dan $\mathrm{Ha}$ diterima sehingga dapat disimpulkan bahwa produktivitasberpengaruh signifikan secara parsial terhadap penyerapan tenaga kerja industri kecil di Sebatik.

Hasil Uji-F (pengujian secara $\underline{\text { simultan }}$ 
Hasil uji $\mathrm{F}$ pada penelitian ini dapat dilihat pada tabel berikut ini

Tabel 11.Uji F Hasil Uji Anova

\begin{tabular}{|c|c|}
\hline F & Sig \\
\hline 1,699 & 0,176 \\
\hline
\end{tabular}

Sumber: Data Primer Diolah, 2018

Hasil uji F pada penelitian ini dapatkan nilai $\mathrm{F}$ hitung sebesar 1,699 dengan angka signifikansi ( $\mathrm{P}$ value) sebesar0,176> 0,05 dan nilai $\mathrm{F}$ hitung $1,699<$ dari nilai $\mathrm{F}$ tabel 2,042. Atas perbandingan tersebut, maka $\mathrm{H} 0$ di terimadan Ha ditolak atau variabel upah (X1), modal(X2), teknologi (X3), dan produktivitas (X4) tidak mempunyai pengaruh signifikansecara bersama-sama terhadap variabel penyerapan tenaga kerja $(\mathrm{Y})$.

$\underline{\text { Hasil Koefisien Determinasi (R2) }}$

Koefisien determinasi (R2) menunjukkan seberapa besar variabel-variabel independen dalam mempengaruhi variabel dependen.Kisaran nilai koefisien determinasi (R2) adalah $0 \leq$ (R2)1.Model dikatakan semakin baik apabila nilai mendekati 1 atau $100 \%$.

Tabel 12 Model Summary

\begin{tabular}{|c|c|c|c|c|}
\hline $\begin{array}{c}\text { Mo } \\
\text { del }\end{array}$ & $\mathbf{R}$ & $\begin{array}{c}\mathbf{R} \\
\text { Squa } \\
\text { re }\end{array}$ & $\begin{array}{c}\text { Adj } \\
\text { uste } \\
\text { d R } \\
\text { Squ } \\
\text { are }\end{array}$ & $\begin{array}{c}\text { Std. } \\
\text { Error } \\
\text { of the } \\
\text { Estim } \\
\text { ate }\end{array}$ \\
\hline 1 & 0,43 & 0,18 & 0,07 & 0,255 \\
& 0 & 5 & 6 & 80 \\
\hline
\end{tabular}

Sumber: Data Primer Diolah, 2018
Berdasarkan tabel di atas diketahui R Square sebesar 0,185. Dari hasil tersebut dapat disimpulkan bahwa variabel upah (X1), modal (X2), teknologi (X3) dan produktivitas (X4) dapat menerangkan variabel penyerapan tenaga kerja (Y) sebesar18,5\%, sedangkan sisanya sebesar81,5\% diterangkan oleh faktor-faktor lain yang tidak terdapat didalam model.

\section{$\underline{\text { Pembahasan }}$}

1. Pengaruh Upah Terhadap Penyerapan Tenaga Di Sebatik Hasil uji hipotesis (Uji t) menunjukkan bahwa upah tidak berpengaruh signifikan terhadap penyerapan tenaga kerja.Artinya tinggi rendahnya upah tenaga kerja tidak akan mempengaruhi penyerapan tenaga kerja jika industri tersebut sedang tidak membutuhkan tambahan tenaga kerja.Hal ini berarti bahwa upah tidak mempengaruhi penyerapan tenaga kerja industri kecil percetakan di Sebatik

2. Pengaruh Modal Terhadap Penyerapan Tenaga Di Sebatik Hasil uji hipotesis (Uji t) menunjukkan bahwa modal tidak berpengaruh signifikan terhadap penyerapan tenaga kerja. Artinya dengan bertambahnya atau berkuragnya jumlah modal pengusaha tersebut tidak mengurangi atau menambah tenagan kerja di sebabkan pengusaha tersebut lebih menambahkan hasil produksi 
dari pada menambah tenaga kerja. Hal ini berarti bahwa modal tidak mempengaruhi penyerapan tenaga kerja industri kecil percetakan di Sebatik.

3. Pengaruh Teknologi Terhadap Penyerapan Tenaga Di Sebatik Hasil uji hipotesis (Uji t) menunjukkan bahwa teknologi tidak berpengaruh signifikan terhadap

4. Pengaruh Produktivitas Terhadap Penyerapan Tenaga Di Sebatik Hasil uji hipotesis (Uji t) menunjukkan bahwa produktivitas berpengaruh signifikan terhadap penyerapan tenaga kerja. Hal ini berarti bahwa produktivitasakan

mempengaruhi penyerapan tenaga kerja industri kecil percetakan di Sebatik.Bila produktivitas meningkat maka pengusaha menambah jumlah tenaga kerja.Sebaliknya, bila produktivitas turun maka pengusaha tersebut tidak menyerap tenaga kerja

\section{KESIMPULAN}

Dari hasil penelitian (Ujit) yang telah dilakukan dapat ditarik kesimpulan bahwa upah (X1), modal (X2), teknologi (X3)tidak berpengaruh signifikan terhadap penyerapan tenaga kerja dan produktivitas (X4) berpengaruh signifikan terhadap penyerapan tenaga kerja di daerah Sebatik. Sedangkan hasil penelitian (Uji F) upah (X1), modal (X2), teknologi (X3) dan produktivitas (X4) mempunyai pengaruh yang tidak signifikan secara bersama-sama terhadap variabel penyerapan tenaga kerja di daerah Sebatik.

\section{SARAN}

Berdasarkan hasil dan pembahasan mengenai upah, modal, teknologi dan produktivitas terhadap penyerapan tenaga kerja industri kecil di Sebatik, saran yang dapat penulis smpaikan adalah:

1. Para pengusaha perlu modal untuk menyediakan tambahan alat teknolgi misalnya mesin foto copy sehingga mendapatkan hasil produksi yang lebih baik dalam rangka untuk menambah penggunaan tenaga kerja. Penambahan penggunaan tenaga kerja akan dapat meningkatkan output perusahaan hal ini dikarenakan perusahaan yang ada masih lebih memanfaatkan penggunaan tenaga kerja daripada penggunaan mesinmesin moderen.

2. Pemerintah diharapkan untuk lebih memprioritaskan peminjaman modal untuk para pengusaha industri percetakan di Sebatik agar para pengusaha dapat mengembangkan usahanya dengan baik dengan modal yang memadai. Pemerintah atau pihak bank maupun lembaga keuangan lainnya agar mempermudah akses modal dengan syaratsyarat yang tidak memberatkan bagi pengusaha kecil dan rumah 
tangga agar para pengusaha dapat mengembangkan usahanya.

3. Untuk meningkatkan permintaan tenaga kerja dapat dilakukan dengan meningkatkan unit usaha yang ada atau juga dapat mengembangkan usaha yang telah ada, hal ini sangat membantu dalam penyerapan tenaga kerja.

4. Dalam menentukan upah seharusnya pihak perusahaan lebih memperhatikan akan keadaan yang sedang terjadi terutama akan kebutuhan hidup yang semakin meningkat. dan apabila pihak perusahaan menambah jumlah pekerja tidak sewenangwenang dalam pemberian upah, diharapkan setiap perusahaan meskipun berskala kecil dan menengah memiliki serikat pekerja yang mampu berperan aktif dalam melindungi hak-hak pekerja

\section{DAFTAR PUSTAKA}

BPS

Kabupaten

Nunukan.(2015a).

Kecamatan Sebatik dalam angka 2015. Nunukan: BPS Kabupaten Nunukan.

BPS. 2015. Tentang Ketenagakerjaan.

Nunukan: BPS

Kabupaten Nunukan

Divianto. 2014. Pengaruh Upah, Modal, Produktivitas, dan Teknologi Terhadap Penyerapan Tenaga Kerja Pada Usaha Kecil-
Menengah dikota

Palembang. Palembang:

Politeknik Negeri

Sriwijaya.

Ghozali, Imam, 2006. Aplikasi

Analisis Multivariate

Dengan Program SPSS.

Badan Penerbit

Universitas Diponogoro

Semarang

Miarso, Yusufhadi. 2007.

Menyamai Benih

Teknologi Pendidikan.

Kencana. Jakarta

Sinungan, Muchdansyah. 2005.

Produktivitas apa dan

Bagaimana. Bina

Aksara: Jakarta

Subandi. 2006. Sistem Ekonomi Indonesia, Bandung

Sugiyono, 2013, Statistika Untuk Penelitian. Bandung: Alfabeta

Sumarsono, Sonny. 2003. Ekonomi Manajemen Sumberdaya Manusia dan Ketenagakerjaan. Yogyakarta: Graha Ilmu

Zamrowi, Taufik, M. 2007. Analisa Penyerapan Tenaga Kerja Pada Industri Mebel di Kota Semarang. Skripsi, Universitas Diponogoro. 